\title{
Effects of heme oxygenase isozymes on Leydig cells steroidogenesis
}

\author{
Barbara Piotrkowski ${ }^{1,2, *}$, Casandra M Monzón ${ }^{1, *}$, Romina M Pagotto ${ }^{1}$, Cecilia G Reche ${ }^{1}$, Marcos Besio ${ }^{1}$, \\ Cora B Cymeryng ${ }^{3}$ and Omar P Pignataro ${ }^{1,4}$
}

\author{
${ }^{1}$ Laboratory of Molecular Endocrinology and Signal Transduction, Institute of Biology and Experimental Medicine-CONICET, Vuelta de Obligado 2490, \\ CP 1428 Buenos Aires, Argentina \\ ${ }^{2}$ Physical Chemistry-PRALIB, School of Pharmacy and Biochemistry, University of Buenos Aires, Junin 956, 2nd Floor, CP 1113 Buenos Aires, Argentina \\ ${ }^{3}$ Department of Human Biochemistry, CEFYBO-CONICET, School of Medicine, University of Buenos Aires, Paraguay 2155, 5th Floor, CP 1121 Buenos Aires, \\ Argentina \\ ${ }^{4}$ Department of Biological Chemistry, School of Sciences, University of Buenos Aires, Int Guiraldes 2160, CP 1428 Buenos Aires, Argentina \\ (Correspondence should be addressed to O P Pignataro at Laboratory of Molecular Endocrinology and Signal Transduction, Instituto de Biología y Medicina \\ Experimental (IBYME-CONICET); Email: pignatar@dna.uba.ar) \\ *(B Piotrkowski and C M Monzón contributed equally to this work)
}

\begin{abstract}
In the present study, we demonstrate the expression of heme oxygenase (HO) isozymes, $\mathrm{HO}-1$ and $\mathrm{HO}-2$ (listed as HMOX1 and HMOX2 in the MGI Database), in MA-10 Leydig tumor cells and its effect on steroidogenesis. The wellknown $\mathrm{HO}$ inducer, hemin, increased both $\mathrm{HO}-1$ and $\mathrm{HO}-2$ protein levels and $\mathrm{HO}$-specific activity. Induction of $\mathrm{HO}$ by hemin inhibited basal, hCG-, and dibutyryl cAMP (db-cAMP)-induced steroidogenesis in a reversible way. When we studied the effect of $\mathrm{HO}$ isozymes along the steroid synthesis, we found that steroidogenic acute regulatory protein levels were decreased, and the conversion of cholesterol to pregnenolone was inhibited by hemin treatment, with no changes in the content of cholesterol side-chain cleavage enzyme (P450scc). hCG and db-cAMP
\end{abstract}

also stimulated the expression of $\mathrm{HO}-1$ and $\mathrm{HO}-2$, and $\mathrm{HO}$ enzymatic activity in MA-10 cells. Basal and hCG-stimulated testosterone synthesis was also inhibited by hemin in rat normal Leydig cells. Taken together, these results suggest that: i) at least one of $\mathrm{HO}$ products (presumably carbon monoxide) inhibits cholesterol transport to the inner mitochondrial membrane and Leydig cell steroidogenesis by binding to the heme group of the cytochrome P450 enzymes, in a similar way as we described for nitric oxide, and ii) hCG stimulation results in the induction of an antioxidant enzymatic system $(\mathrm{HO})$ acting as a cytoprotective mechanism in Leydig cells, as already demonstrated in the adrenal gland.

Journal of Endocrinology (2009) 203, 155-165

\section{Introduction}

Steroid synthesis depends on two limiting steps: the first one is at the level of the transport of cholesterol to the inner mitochondrial membrane, a process dependent on the steroidogenic acute regulatory protein (STAR; Stocco 2001); and the second key step is the conversion of cholesterol to pregnenolone $\left(\mathrm{P}_{5}\right)$ by the cholesterol side-chain cleavage enzyme system (Stocco \& Clark 1996). In testis, Leydig cells are interstitial cells that synthesize testosterone through cytochrome P450-dependent monooxygenases. Although steroidogenesis in Leydig cells is primarily under LH control, a number of paracrine/autocrine factors have been suggested to play a role in the modulation of this hormone action (Ascoli et al. 2002, Hales 2002, Mondillo et al. 2005, 2007, Stocco et al. 2005). Among them, the inhibitory effect of nitric oxide (NO) on steroid synthesis in Leydig cells had been previously demonstrated in our laboratory (Del Punta et al. 1996).
Heme oxygenases $(\mathrm{HO})$ catalyze the first and rate-limiting step in the oxidative degradation of heme into three products: carbon monoxide (CO); biliverdin; which is rapidly converted into bilirubin by biliverdin reductase; and free iron, which is sequestered into ferritin (Maines 1997). To date, three isoforms have been identified: HO-1 (HMOX1), HO-2 (HMOX2), and HO-3F (McCoubrey et al. 1997, Maines 2005). While HO-1 (32 kDa) expression can be induced by its own substrate heme, and several other stress stimuli such as heavy metals, lipopolysaccharide (LPS), inflammatory mediators, and oxidized low-density proteins (Otterbein \& Choi 2000), the other two isoforms, HO-2 (36 kDa) and HO-3 (33 kDa), are constitutively expressed (McCoubrey et al. 1992, 1997). However, recent studies have shown that corticosterone, estradiol, and a photic signal can induce HO-2 expression in testis (Liu et al. 2000), endothelial cells (Tschugguel et al. 2001), and retina (Sacca et al. 2003) respectively. Both $\mathrm{HO}-1$ and $\mathrm{HO}-2$ isoforms have been 
detected in diverse organs, including reproductive ones such as testes (Trakshel \& Maines 1988, Ewing \& Maines 1995), placenta (Lyall et al. 2000), uterus (Acevedo \& Ahmed 1998), and ovary (Alexandreanu \& Lawson 2003).

$\mathrm{CO}$ is a gaseous second messenger that shares several biological properties with $\mathrm{NO}$, including the activation of guanylate cyclase, signal transduction, and gene regulation (Verma et al. 1993, Zhuo et al. 1993). Based on the similarities with $\mathrm{NO}$, recent studies have suggested a possible regulatory role for $\mathrm{CO}$ on steroid production in ovary and adrenal gland (Alexandreanu \& Lawson 2003, Pomeraniec et al. 2004). In addition, Ozawa et al. (2002) reported that CO derived from HO-1 in Leydig cells modulated spermatogenesis and triggered apoptosis of germ cells under stress conditions (Ozawa et al. 2002). Besides, in humans, increased HO-1 expression in Leydig cells improved spermatogenesis in varicocele condition (Shiraishi \& Naito 2005), and HO1-derived CO in testicular Sertoli cells may have a functional role on soluble guanylyl cyclase-dependent cGMP production in the seminiferous tubule (Middendorff et al. 2000). Furthermore, numerous studies proposed that the activity of $\mathrm{HO}$ system might provide cellular protection against oxidative stress (Stocker 1990, Maines 1997, Niess et al. 1999, Pomeraniec et al. 2004, Shiraishi \& Naito 2005).

Although HO-1 and HO-2 isoforms have been detected in the rat testes, the biochemical mechanisms by which the $\mathrm{HO} / \mathrm{CO}$ system regulates steroidogenesis have not been investigated so far. So, the aim of this study was to analyze the expression levels of both $\mathrm{HO}$ isoforms and the influence of $\mathrm{HO}$ activity on steroid production in MA-10 Leydig cells.

\section{Materials and Methods}

\section{Materials}

Purified hCG (CR-127, 14; $900 \mathrm{IU} / \mathrm{mg}$ ) was a gift from the National Hormone and Pituitary Program, National Institute of Diabetes and Digestive and Kidney Diseases (Bethesda, MD, USA). The specific antibody for progesterone $\left(\mathrm{P}_{4}\right)$ and testosterone was a gift from Dr G D Niswender (Animal Reproduction and Biotechnology Lab, Colorado State University, Fort Collins, CO, USA). HO-1 and HO-2 antibodies were from StressGen Biotechnologies Corp. (Victoria, BC, Canada). STAR and cytochrome P450scc (P450scc or CYP11A) antibodies were a gift from Dr Walter L Miller (University of California, San Francisco) and Dr Dale B Hales (University of Illinois at Chicago) respectively. Peroxidase-conjugated anti-IgG antibodies were purchased from Amersham Pharmacia. Cell culture supplies and plastic ware were obtained from Gibco-BRL and Corning (Corning, NY, USA) respectively. Hemin (a well-known $\mathrm{HO}$ inducer) and dibutyryl cAMP (db-cAMP, the permeable analog of the second messenger) were purchased from Sigma. Collagenase was from Worthington (Freehold, NJ, USA).
Other reagents used were of the best grade available and were obtained from commonly used suppliers.

\section{Cellular culture of MA-10 Leydig cells}

The MA-10 cell line (kindly provided by Mario Ascoli, University of Iowa, Ames, IA, USA) is a clonal strain of Leydig tumor cells that secrete $\mathrm{P}_{4}$ rather than testosterone as a major steroid. This cell line provides a suitable model system for the study of gonadotropin actions and regulation of differentiated functions of Leydig cells, as they behave like normal steroidogenic cells in several aspects, including the stimulation of steroid production by $\mathrm{LH} / \mathrm{hCG}$ in a cAMPdependent pathway. The origin and handling of MA-10 cells have already been described (Ascoli 1981, Pignataro \& Ascoli 1990b). Cells were plated in 100-mm Petri dish plates (for immunoblot analysis and $\mathrm{HO}$ activity) or in $24 \times 16-\mathrm{mm}$ well plates (for steroidogenesis experiments) on day 0 at a density of $3 \times 10^{6}$ cells $/$ dish or $1.25 \times 10^{5}$ cells/well, and in a total volume of 10 or $1 \mathrm{ml}$ of growth medium (Waymouth MB752/1, modified to contain $1 \cdot 1 \mathrm{~g} / 1 \mathrm{NaHCO}_{3}, 20 \mathrm{mmol} / 1$ Hepes, $50 \mathrm{mg} / \mathrm{ml}$ gentamycin, and $15 \%$ (v/v) horse serum, $\mathrm{pH}$ 7.4) respectively. The cells were maintained in a humidified atmosphere containing 5\% $\mathrm{CO}_{2}$ and were used on day 3 . At this time, the cell density was $\sim 10 \times 10^{6}$ cells/ dish or $5 \times 10^{5}$ cells/well. On this day, the cells were washed with $1 \mathrm{ml}$ warm serum-free medium supplemented with $1 \mathrm{mg} / \mathrm{ml} \mathrm{BSA} \mathrm{(assay} \mathrm{medium).} \mathrm{Incubations} \mathrm{were} \mathrm{performed}$ in a total volume of $7 \mathrm{ml}$ (for dishes) or $0.5 \mathrm{ml}$ (for wells) assay medium at $37{ }^{\circ} \mathrm{C}$ with the corresponding additions as described in each figure. After $5 \mathrm{~h}$ (unless other indicated), media were collected, and $\mathrm{P}_{4}$ was measured by RIA (Pignataro \& Ascoli 1990a). The intra- and inter-assay variations were $8 \cdot 0$ and $14 \cdot 2 \%$ respectively. Cells were treated as describes below. When hemin was used for experiments, 30-min pretreatment with the compound was done.

To study the reversibility of the inhibitory effect of the HO inducer on steroid synthesis, MA-10 cells were incubated in the absence or presence of $10 \mu \mathrm{mol} / 1$ hemin with or without $0 \cdot 2 \mathrm{mmol} / \mathrm{l} \mathrm{db}$-cAMP. After $5 \mathrm{~h}$, media were collected for $\mathrm{P}_{4}$ determination (day 1). Cells were washed and incubated with hemin-free fresh medium for an additional $24 \mathrm{~h}$. By the end of this incubation period, cells were stimulated with $1 \mathrm{mmol} / 1$ db-cAMP for $5 \mathrm{~h}$ (day 2).

\section{Rat Leydig cell isolation and testosterone production}

For all the experiments, Leydig cells were isolated from a pool of 16 testes obtained from eight adult Sprague-Dawley rats (60 days old, 200-250 g, Charles River descendants, Animal Care Lab, IByME, Buenos Aires, Argentina), as previously described (Charreau et al. 1981, Pignataro et al. 1983, Mondillo et al. 2009). Animals were housed in groups in an air-conditioned room with lights on from 0700 to 1900 h. They were given free access to laboratory chow and tap water. Animals were killed by $\mathrm{CO}_{2}$ asphyxia according to 
protocols for animal use approved by the institutional animal care and use committee (IBYME-CONICET) that follows $\mathrm{NIH}$ guidelines.

The cell pellets were resuspended in M199-0.1\% (w/v) BSA and purified by fractionation on a three-layer Percoll density gradient $(26,34$, and $60 \%(\mathrm{v} / \mathrm{v}))$. The purity of Leydig cells obtained was over $92 \%$, as assessed by histochemical staining

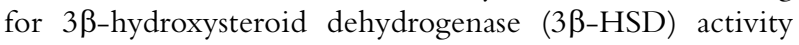
(Payne et al. 1980). Less than 1.7 and $1.2 \%$ of the contaminating cells in the Leydig cell preparations were positive macrophages for ED-1 and ED-2 antigens respectively (Frungieri et al. 2006, Mondillo et al. 2009). The remaining cell types had the morphology of either peritubular cells or endothelial cells.

The pellets, enriched in Leydig cells, were gently resuspended in M199 containing $1.2 \mathrm{~g} / 1 \mathrm{NaHCO}_{3}$, $20 \mathrm{mmol} / 1$ Hepes, $0 \cdot 1 \mathrm{mmol} / 1$ 1-methyl-3-isobutylxanthine, and $0.5 \%(\mathrm{w} / \mathrm{v}) \mathrm{BSA}$. Incubations were done in plastic tubes in a volume of $500 \mu \mathrm{l}\left(5 \times 10^{5}\right.$ cells/tube), at $34^{\circ} \mathrm{C}$ with shaking, for $5 \mathrm{~h}$. The samples were then centrifuged at $800 \boldsymbol{g}$ for $5 \mathrm{~min}$, and the supernatants were used to determine testosterone by RIA (Mondillo et al. 2005). The intra- and inter-assay variations were $7 \cdot 3$ and $13 \cdot 2 \%$ respectively.

\section{MA-10 cell lysates and mitochondria isolation}

After collecting the media, MA-10 cells were scrapped and centrifuged at $800 \boldsymbol{g}$ for $10 \mathrm{~min}$. The resulting pellet was resuspended in a medium containing $0 \cdot 25 \mathrm{~mol} / 1$ sucrose, $0 \cdot 1 \mathrm{mmol} / 1$ EDTA, $10 \mathrm{mmol} / \mathrm{l}$ Tris- $\mathrm{HCl}(\mathrm{pH} \mathrm{7 \cdot 4})$, with proteases inhibitors $(10 \mathrm{mg} / \mathrm{ml}$ leupeptine, $5 \mathrm{mmol} / \mathrm{l} \mathrm{NaF}$, $2.5 \mathrm{mmol} / 1$ phenylmethylsulfonyl fluoride, and $50 \mathrm{mmol} / \mathrm{l}$ sodium orthovanadate), and briefly sonicated. Cell lysates were centrifuged at $800 \mathrm{~g}$ for $10 \mathrm{~min}$ to remove cell debris, and the resulting supernatant was further centrifuged at $10000 \boldsymbol{g}$ for $20 \mathrm{~min}$. The pellet obtained was a crude mitochondrial fraction, and the supernatant was further centrifuged at $100000 \boldsymbol{g}$ for $1 \mathrm{~h}$ to obtain the microsomal fraction. Protein concentrations were measured using the Bradford assay for total protein.

\section{HO activity}

$\mathrm{HO}$ activity was determined in microsomal fractions from MA-10 cells by monitoring the conversion of heme into bilirubin as previously described (Llesuy \& Tomaro 1994). In brief, $200 \mu \mathrm{l}$ of the reaction mixture $(0.2 \mathrm{mg} / \mathrm{ml} \mathrm{micro-}$ somal protein, $0.33 \mathrm{mmol} / 1$ hemin, $0.5 \mathrm{mg} / \mathrm{ml}$ rat liver cytosol, $0 \cdot 2 \mathrm{mmol} / 1 \mathrm{MgCl}_{2}, 2 \mathrm{mmol} / 1$ glucose-6-phosphate, 1.62 units/ml glucose-6-phosphate dehydrogenase, $0.5 \mathrm{mmol} / 1 \mathrm{NADPH}$, and $25 \mathrm{mmol} / 1$ potassium phosphate buffer $(\mathrm{pH} 7 \cdot 4)$ ) were incubated at $37^{\circ} \mathrm{C}$ for $2 \mathrm{~h}$. The reaction mixture was extracted with $0.6 \mathrm{ml}$ chloroform, and the bilirubin concentration, in the chloroform layer, was spectrophotometrically measured by the difference in absorbance between 464 and $530 \mathrm{~nm}$ (extinction coefficient $40 \mathrm{mmol} / \mathrm{l}$ per $\mathrm{cm}$ ). Readings for samples prepared in the absence of cell homogenate (blank) were subtracted from all other values. $\mathrm{HO}$ enzyme activity is indicated as nanomole of bilirubin formed per milligram of protein per hour.

\section{Western blot analysis and immunodetection of proteins}

HO isoforms, STAR, and P450scc (listed as CYP11A1 in MGI Database), were determined in microsomal (HO) and mitochondrial (STAR and P450scc) fractions. Equal amounts of protein per sample $(30-40 \mu \mathrm{g})$ were boiled for $5 \mathrm{~min}$ in SDS-PAGE-loading buffer and then separated in $15 \%(\mathrm{w} / \mathrm{v})$ polyacrylamide gels. After electrophoresis, proteins were electrotransferred to polyvinylidene difluoride (PVDF) membranes for $30 \mathrm{~min}$ at $10 \mathrm{~V}$ in a Trans-Blot SD semi-dry electrophoretic transfer cell (Bio-Rad Laboratories Inc). PVDF membranes were blocked in $5 \%(\mathrm{w} / \mathrm{v})$ nonfat dry milk in $50 \mathrm{mmol} / 1$ Tris- $\mathrm{HCl}(\mathrm{pH} 7 \cdot 4), 0.15 \mathrm{~mol} / \mathrm{l} \mathrm{NaCl}$, $0 \cdot 25 \%(\mathrm{v} / \mathrm{v})$ Tween-20, for $2 \mathrm{~h}$ at room temperature ( $\mathrm{HO}$ and STAR) or overnight at $4{ }^{\circ} \mathrm{C}$ (P450scc), and then incubated overnight with the corresponding dilution of the primary antibody at $4{ }^{\circ} \mathrm{C}$ : anti-HO-1 and HO-2, 1/1000; anti-STAR, 1/5000 (Bose et al. 1999); anti-P450scc, 1/2000 (Hales et al. 2000, Allen et al. 2007). Peroxidase-conjugated secondary antibodies were incubated for $90 \mathrm{~min}$ at room temperature. The membranes were washed, and to reveal bound secondary antibody, a chemiluminescence-enhanced kit and autoradiography were used. The intensity of immunospecific bands was quantified using ImageJ software $(\mathrm{NIH}$, Bethesda, MD, USA; Stocco \& Clark 1996). To normalize samples for protein loading, antibodies against $\alpha$-actin or cytochrome $c$ were used.

\section{Reverse transcription-PCR}

Total RNA was extracted from MA-10 cells with TRIzol reagent (Invitrogen) according to the manufacturer's instructions. Before the reverse transcription (RT) step, RNA was subjected to deoxyribonuclease treatment (DNase 1 amplification grade, Life Technologies Inc.) to eliminate any possible DNA contamination. RT was then performed on total RNA $(2 \mu \mathrm{g})$. Briefly, cDNA synthesis was carried out using $200 \mathrm{U}$ Moloney murine leukemia virus reverse transcriptase (Promega Corp.), $8 \mu \mathrm{mol} / \mathrm{l}$ random primers, $0.5 \mathrm{mmol} / \mathrm{l}$ dNTP, and $25 \mathrm{U}$ rRNAsin ribonuclease inhibitor in a total reaction volume of $25 \mu \mathrm{l}$. RT was performed at $42^{\circ} \mathrm{C}$ for $1 \mathrm{~h}$, and the reaction was stopped by heating the mixture at $95^{\circ} \mathrm{C}$ for $5 \mathrm{~min}$. PCRs were carried out in a Tpersonal Thermocycler (Biometra Biomedizinische Analytik, Göttingen, Germany) and were performed using $4 \mu \mathrm{cDNA}$ and the PCR mix containing specific sense and antisense primers, dNTPs, Taq polymerase (Invitrogen), reaction buffer, and PCR grade water.

Primers used for the amplification of Star CDNA were: forward: 5'-AAGGATTAAGGCACCAAGCTGTGC-3'; reverse: $5^{\prime}$-CTCTGATGACACCACTCTGCTCCGG-3' (588 bp fragment). 18S RNA was used in the semiquantitative RT-PCR protocol as an internal control to 
normalize, forward primer $5^{\prime}$-ACGGAAGGGCACCACCAGGA-3'; reverse primer 5'-CACCACCACCCACGGAATCG-3' (125 bp fragment).

PCRs were carried out with a first step at $94^{\circ} \mathrm{C}$ for $3 \mathrm{~min}$ and then the corresponding number of cycles of denaturation at $94{ }^{\circ} \mathrm{C}$ for $45 \mathrm{~s}$, annealing at $55{ }^{\circ} \mathrm{C}$ for $30 \mathrm{~s}$, and elongation at $72{ }^{\circ} \mathrm{C}$ for $90 \mathrm{~s}$ plus a final incubation at $72{ }^{\circ} \mathrm{C}$ for $10 \mathrm{~min}$. Reaction products were electrophoresed on $1.5 \%(\mathrm{w} / \mathrm{v})$ agarose gels in $40 \mathrm{mmol} / 1$ Tris acetate and $2 \mathrm{mmol} / 1$ EDTA (pH 8) stained with ethidium bromide, photographed, and quantified with FluorChem software 4.1.0. (Alpha Innotech Corporation, Image Processing Solutions, San Leandro, CA, USA).

\section{Statistical analysis}

All values are expressed as mean \pm s.E.M. of $n$ experiments. Differences between groups were analyzed by factorial oneway ANOVA. When the ANOVA was significant $(P<0 \cdot 05)$, post hoc comparisons (Dunnett's or Tukey's test) were made to determine the statistical levels of difference between groups using GraphPad InStat version 4.0 for Windows (GraphPad Software, San Diego, CA, USA).

\section{Results}

Expression of HO isozymes in MA-10 Leydig cells

In order to analyze the expression profile of $\mathrm{HO}$ isozymes in these cells, we first studied the basal expression levels of both isoforms and the effect of $10 \mu \mathrm{mol} / 1$ hemin (a well-known $\mathrm{HO}$ inducer) in MA-10 cells. As shown in Fig. 1A, both HO-1 and $\mathrm{HO}-2$ isoforms are expressed in MA-10 cells. In addition, hemin treatment resulted in significantly increased levels of both isoforms $(P<0 \cdot 001$, Fig. $1 \mathrm{~A}$ and $\mathrm{B})$. In agreement with protein expression results, $\mathrm{HO}$-specific activity was increased three times by hemin treatment (Fig. 1C).

\section{Effect of HO isozymes on MA-10 cells steroidogenesis}

Once the expression of HO isozymes in MA-10 cells was demonstrated, the involvement of this enzyme in the modulation of steroid synthesis was analyzed. As shown in Fig. 2, preincubation of the cells with $10 \mu \mathrm{mol} / 1$ hemin for $30 \mathrm{~min}$ followed by stimulation with submaximal concentrations of hCG $(1 \mathrm{ng} / \mathrm{ml})$ or db-cAMP $(0 \cdot 2 \mathrm{mmol} / \mathrm{l})$ or maximal concentrations of db-cAMP $(1 \mathrm{mmol} / \mathrm{l})$ for $5 \mathrm{~h}$ resulted in a significant inhibition of $\mathrm{P}_{4}$ production $(60,38$ and $35 \%$ inhibition respectively, $P<0 \cdot 05)$. Basal $\mathrm{P}_{4}$ synthesis was also inhibited in the presence of hemin.

The inhibitory effect of hemin on MA-10 Leydig cell steroidogenesis was not due to a cytotoxic effect of the drug as the percentage of viable cells per well, determined by trypan blue exclusion staining after the incubation, was similar between the hemin-treated cells (95\%) and the controls (93\%). To confirm that hemin treatment was not causing a
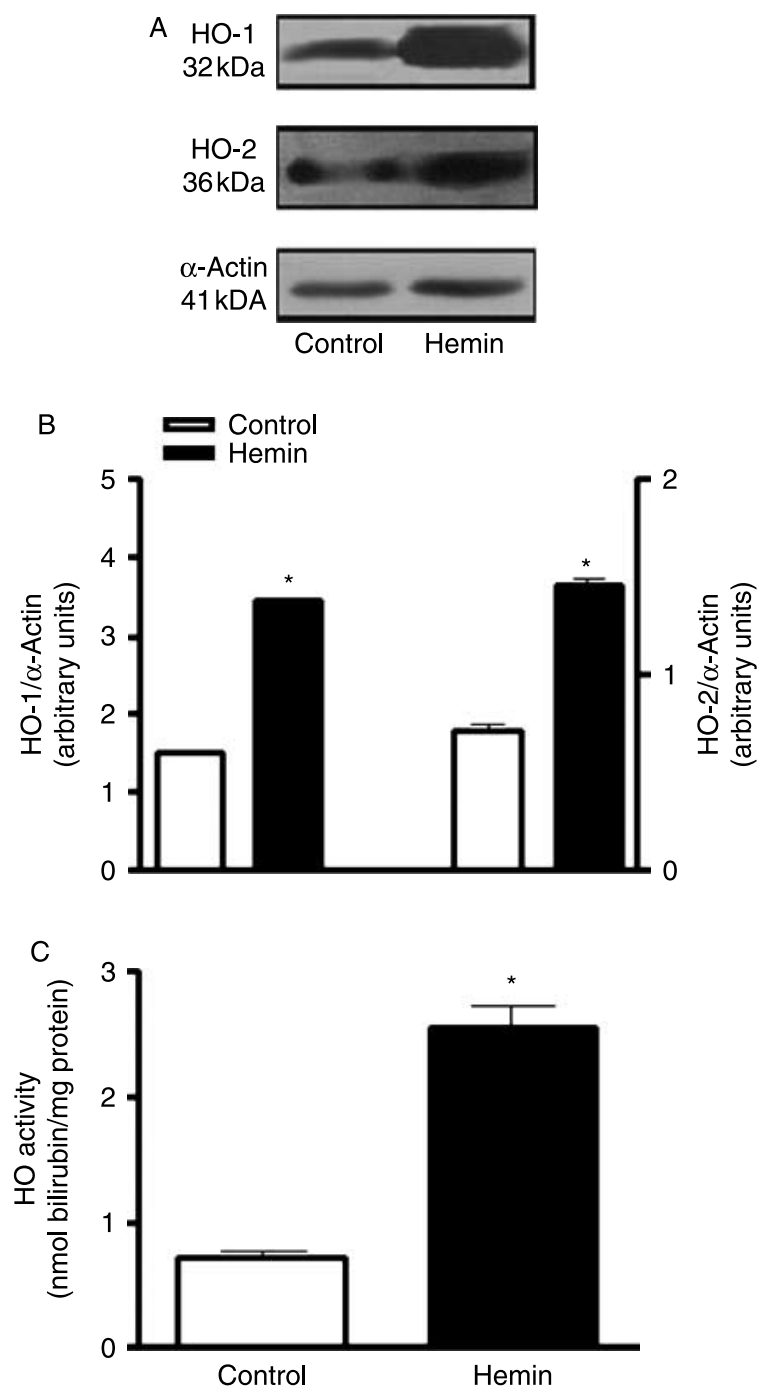

Figure 1 Effect of hemin on $\mathrm{HO}$ protein expression and activity in MA-10 Leydig cells. (A) Representative inmunoblot for HO-1 and $\mathrm{HO}-2$ proteins. Cells were incubated with or without $10 \mu \mathrm{mol} / \mathrm{l}$ hemin for five and a half hours. Media were collected, microsomal fractions from MA-10 cells were isolated, and proteins were analyzed by western blot as described in Materials and Methods; (B) quantification of $\mathrm{HO}$ levels by scanning densitometry, corrected by the corresponding $\alpha$-actin; (C) HO-specific activity was determined in microsomal fractions by monitoring the conversion of heme into bilirubin as described in Materials and Methods. Values are expressed as means \pm S.E.M. of three independent experiments; ${ }^{*} P<0 \cdot 001$ versus control.

permanent effect in the cells, we also examined the reversibility of its effect on steroidogenesis. Table 1 shows that the inhibitory effect detected after incubating the cells in the presence of $10 \mu \mathrm{mol} / 1$ hemin both on basal and db-cAMPstimulated steroid synthesis (35 and 33\% inhibition respectively; day 1) was completely reversed $24 \mathrm{~h}$ after the removal of hemin, as MA-10 cells fully recovered their capacity to respond to a maximal concentration of db-cAMP in day 2 . 


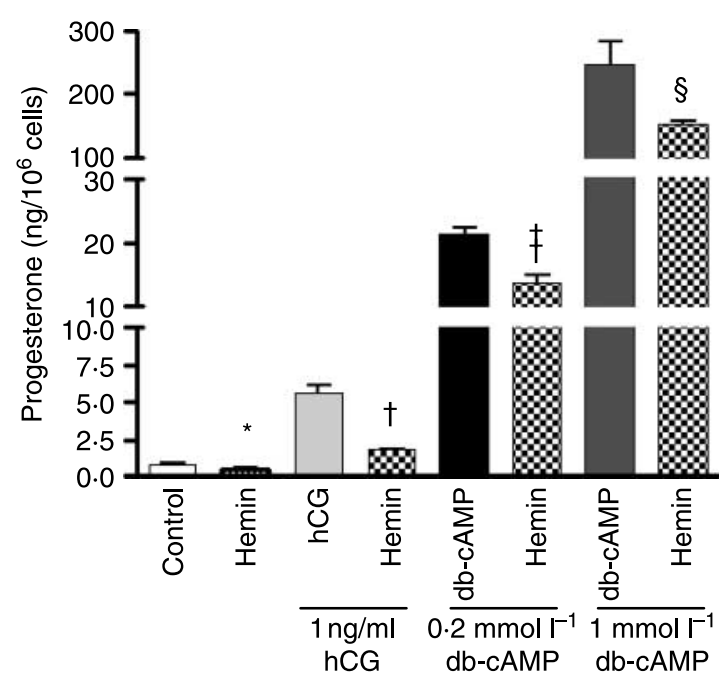

Figure 2 Effect of hemin on progesterone synthesis in MA-10 Leydig cells. Cells were preincubated with or without $10 \mu \mathrm{mol} / \mathrm{l}$ hemin for $30 \mathrm{~min}$. hCG $(1 \mathrm{ng} / \mathrm{ml})$ or db-cAMP $(0 \cdot 2$ or $1 \mathrm{mmol} / \mathrm{l})$ was added, and incubation was continued for an additional $5 \mathrm{~h}$. Values are expressed as means \pm S.E.M. of three independent experiments each performed with three culture wells per condition; ${ }^{*} P<0 \cdot 05$ versus control, ${ }^{+} P<0 \cdot 05 \mathrm{vs} 1 \mathrm{ng} / \mathrm{ml} \mathrm{hCG},{ }^{\ddagger} P<0.05 \mathrm{vs} 0.2 \mathrm{mmol} / \mathrm{l}$ db-cAMP, ${ }^{\S} P<0.05$ vs $1 \mathrm{mmol} / \mathrm{l} \mathrm{db}$-cAMP.

\section{Effect of HO isozymes on STAR expression}

To further characterize the involvement of $\mathrm{HO}$ isozymes on the steroid synthesis, a time-course study of hemin action on the stimulation of HO-1 and STAR protein by hCG was performed (Fig. 3, upper panel). Cells were preincubated with or without $10 \mu \mathrm{mol} / 1$ hemin for $30 \mathrm{~min}$. hCG $(20 \mathrm{ng} / \mathrm{ml})$ was added, and incubation was continued for 1 , 3 , or $5 \mathrm{~h}$. Increase in HO-1 and decrease in STAR protein levels by hemin treatment was noted after $3 \mathrm{~h}$. These effects were still evident after $5 \mathrm{~h}$ of hCG stimulation (Fig. 3A-D; $P<0 \cdot 05$ versus respective hCG).
To confirm if the effect was due to the action of the second messenger (cAMP), we evaluated hemin treatment on $\mathrm{db}$-cAMP-induced STAR protein expression after $5 \mathrm{~h}$ (Fig. 3, lower panel). In agreement with the results obtained with hCG stimulation, db-cAMP-dependent HO-1 induction correlates with a marked decrease in STAR protein levels, suggesting that $\mathrm{HO}$ stimulation could be affecting cholesterol transport to the inner mitochondrial membrane.

To determine whether Star transcription was also affected, a time course of hemin action on hCG-stimulated Star mRNA expression was carried out by semi-quantitative RT-PCR analysis. In contrast to the effects of hemin on STAR protein levels, Fig. 4 shows that hemin treatment results in a marked increase in Star mRNA levels after $3 \mathrm{~h}$ of hCG stimulation, with no effects at 1 and $5 \mathrm{~h}$. These results suggest that $\mathrm{HO}$ induction could regulate STAR expression by modifying, both, its mRNA and protein levels in MA-10 cells.

\section{Involvement of $\mathrm{HO}$ isozymes in the steroidogenic pathway}

To evaluate whether the activity of $\mathrm{HO}$ was affecting any other step in the steroidogenic pathway, we then incubated MA-10 cells in the presence of 22-R-hydroxycholesterol (5 $\mu \mathrm{mol} / 1,22-\mathrm{R}-\mathrm{OH})$, a cholesterol derivative that easily passes through cell membranes, or $\mathrm{P}_{5}(5 \mu \mathrm{mol} / \mathrm{l})$, with or without hemin.

As shown in Fig. 5, the inhibitory effect of hemin was completely prevented by the addition of $\mathrm{P}_{5}$, indicating that the activity of $3 \beta-\mathrm{HSD}$ was not affected by this treatment. In contrast, a significant inhibition of $\mathrm{P}_{4}$ synthesis was still observed when $22-\mathrm{R}-\mathrm{OH}$ was used as a substrate $(P<0 \cdot 05)$. These data suggest that at least one inhibitory effect of $\mathrm{HO}$ on the stimulated steroidogenic pathway seems to occur at the cholesterol side-chain cleavage (P450scc) step.

Since P450scc catalyzes the conversion of cholesterol to $\mathrm{P}_{5}$, the protein content of this enzyme was evaluated after hemin treatment. Figure 6 shows that hemin does not modify P450scc protein expression.

Table 1 Recovery of MA-10 Leydig cell steroidogenesis after $10 \mu \mathrm{mol} / \mathrm{l}$ hemin treatment. MA-10 Leydig cells were preincubated with or without $10 \mu \mathrm{mol} / \mathrm{l}$ hemin for $30 \mathrm{~min}$. db-cAMP $(0 \cdot 2 \mathrm{mmol} / \mathrm{l})$ was added and incubation was continued for $5 \mathrm{~h}$. Media were collected for progesterone determination (day 1 ). Cells were washed and reincubated with hemin-free fresh medium for an additional $24 \mathrm{~h}$. At the end of the incubation, cells were stimulated with db-cAMP $(1 \mathrm{mmol} / \mathrm{l})$ for $5 \mathrm{~h}$ (day 2). Data represent mean \pm s.E.M. of three independent experiments, each performed with two culture wells per condition

Day 2

$$
\mathrm{P}_{4}\left(\mathrm{ng} / 10^{6} \text { cells }\right)
$$

Day 1

Treatment

Control

Hemin

$0 \cdot 2 \mathrm{mmol} / \mathrm{l} \mathrm{db}-\mathrm{cAMP}$

$0 \cdot 2 \mathrm{mmol} / \mathrm{l} \mathrm{db}-\mathrm{cAMP}+$ Hemin

Treatment $\quad \mathrm{P}_{4}\left(\mathrm{ng} / 10^{6}\right.$ cells $)$

${ }^{*} P<0.05$ versus control, ${ }^{\dagger} P<0.05$ vs $0.2 \mathrm{mmol} / \mathrm{l} \mathrm{db}$-cAMP. 

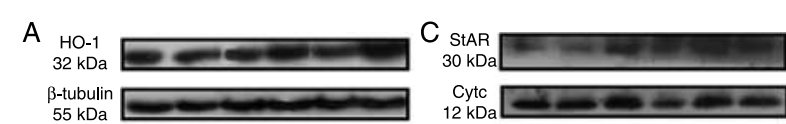

B
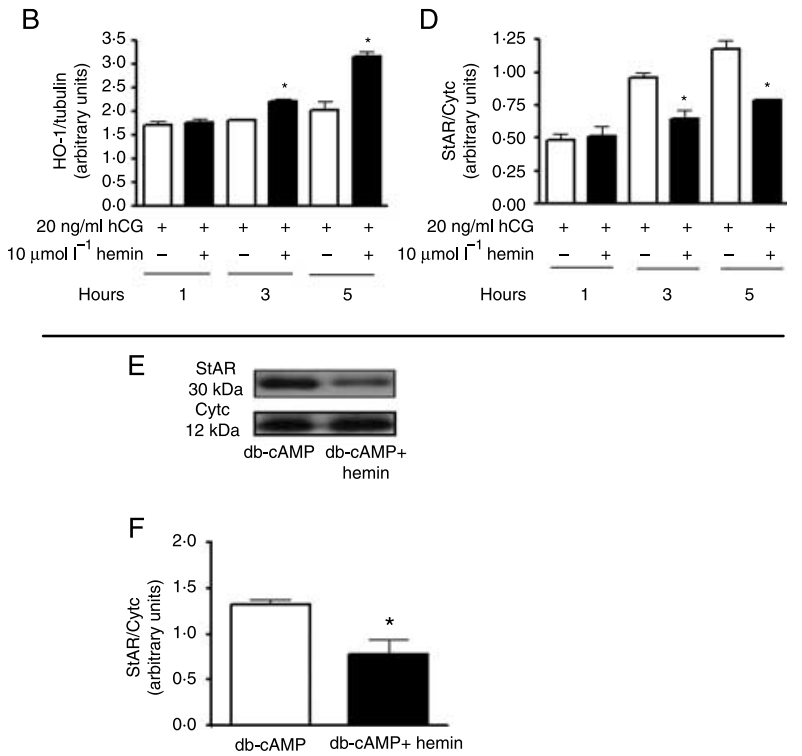

Figure 3 Effect of hemin on HO-1 and STAR protein levels in MA-10 Leydig cells. (A-D) time course of hemin effect on hCGstimulated HO-1 and STAR protein levels. Cells were preincubated with or without $10 \mu \mathrm{mol} / \mathrm{l}$ hemin for $30 \mathrm{~min}$. hCG $(20 \mathrm{ng} / \mathrm{ml})$ was added, and incubation was continued for 1, 3, or $5 \mathrm{~h}$. Media were collected, microsomal and crude mitochondrial fractions from MA-10 cells were isolated, and proteins were analyzed by western blot as described in Materials and Methods. (A) Representative immunoblot for $\mathrm{HO}-1$ protein and the internal control, $\beta$-tubulin $(55 \mathrm{kDa})$; (B) quantification of HO-1 levels by scanning densitometry; (C) representative immunoblot for STAR protein and the internal control cytochrome $c(12 \mathrm{kDa})$; (D) quantification of STAR levels by scanning densitometry. Values are expressed as means \pm S.E.M. Of three independent experiments, $* P<0 \cdot 05$ versus respective hCG. ( $E$ and $F$ ) effect of hemin on db-cAMP-stimulated STAR protein levels. Cells were preincubated with or without $10 \mu \mathrm{mol} / \mathrm{l}$ hemin for $30 \mathrm{~min}$. db-cAMP $(1 \mathrm{mmol} / \mathrm{l})$ was added, and incubation was continued for an additional $5 \mathrm{~h}$. Media were collected, crude mitochondrial fractions from MA-10 cells were isolated, and proteins were analyzed by western blot as described in Materials and Methods. Data were normalized to the $12 \mathrm{kDa}$ internal control cytochrome $c$. (A) Representative immunoblot for STAR protein; (B) quantification of STAR levels by scanning densitometry. Values are expressed as means \pm S.E.M. of three independent experiments, ${ }^{*} P<0.05$ versus db-cAMP.

\section{Regulation of the expression of $H O$ isozymes by $h C G$ or} $d b-c A M P$

As previous results indicated that $\mathrm{HO}-1$ expression was up-regulated by ACTH in adrenal cells (Pomeraniec et al. 2004), the effect of hCG or db-cAMP on the expression levels of $\mathrm{HO}$ isoforms and enzymatic activity in MA-10 cells was studied. Results showed that the addition of $20 \mathrm{ng} / \mathrm{ml}$ hCG or $1 \mathrm{mmol} / 1$ db-cAMP (maximally effective concentrations for the stimulation of steroidogenesis) for $5 \mathrm{~h}$ increased both the expression of $\mathrm{HO}$ isozymes (Fig. 7A and B; $P<0 \cdot 001$ ) and $\mathrm{HO}$-specific activity (Fig. $7 \mathrm{C} ; P<0 \cdot 05$ ).

\section{Effects of HO regulation on rat Leydig cell testosterone production}

Although MA-10 cells are known to preserve most of the characteristic features of Leydig cells, and are a widely used model to study Leydig cell steroidogenesis, they are still tumoral cells that have undergone a series of mutations. It is therefore necessary to validate the cellular model by showing the regulatory effects of $\mathrm{HO}$ on normal Leydig cells steroid production. Thus, we studied the effect of hemin on testosterone production in normal rat Leydig cells. Figure 8 shows that hemin significantly reduced basal and hCGstimulated testosterone production (16 and 20\% inhibition respectively; $P<0 \cdot 01$ ).

\section{Discussion}

In the present study, we demonstrate the presence of both inducible HO-1 (32 kDa) and constitutive HO-2 (36 kDa) isozymes in unstimulated MA-10 cells, a murine cell line derived from Leydig cells. We also show an increase in the expression levels of both $\mathrm{HO}$ isoforms and in $\mathrm{HO}$ activity by hemin. The expression of HO isozymes in rat Leydig cells had been previously detected, as well as the increase in $\mathrm{HO}-1$
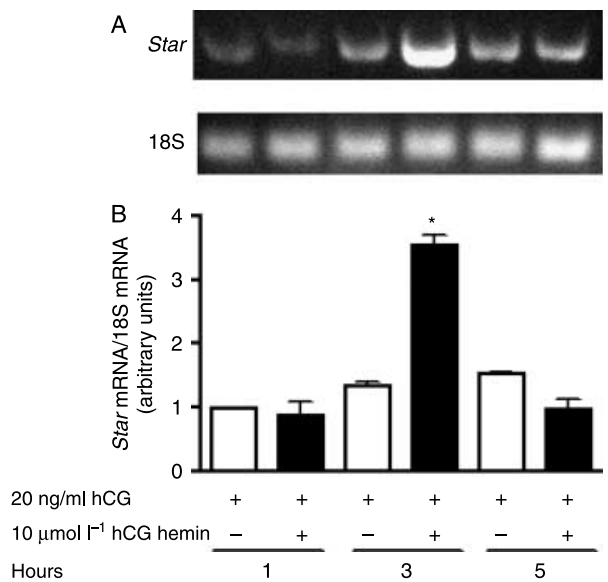

Figure 4 Effect of hemin on Star mRNA levels in MA-10 Leydig cells. Cells were preincubated with or without $10 \mu \mathrm{mol} / \mathrm{l}$ hemin for $30 \mathrm{~min}$. hCG $(20 \mathrm{ng} / \mathrm{ml})$ was added, and incubation was continued for 1,3 , or $5 \mathrm{~h}$. RNA from MA-10 cells were isolated, and Star expression levels were analyzed with RT-PCR as described in Materials and Methods. (A) Representative RT-PCR for Star mRNA; (B) quantification of RT-PCR products of Star. The histogram shows the densitometric analysis of the relative abundance of Star mRNA normalized with the corresponding $18 \mathrm{~S}$. Values are expressed as means \pm s.E.M. of three independent experiments, ${ }^{*} P<0 \cdot 001$ versus respective $\mathrm{hCG}$. 


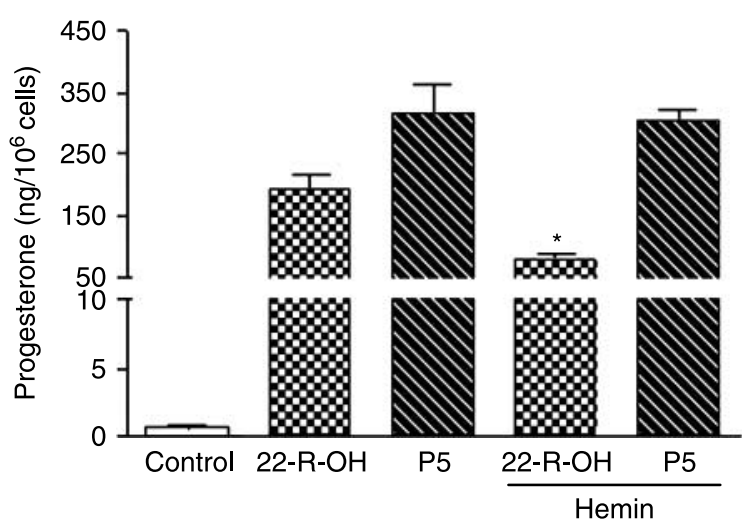

Figure 5 Effect of hemin on progesterone synthesis stimulated by $22 \mathrm{R}$-hydroxycholesterol $(22-\mathrm{R}-\mathrm{OH})$ and pregnenolone $\left(\mathrm{P}_{5}\right)$ in MA-10 Leydig cells. Cells were preincubated with or without $10 \mu \mathrm{mol} / \mathrm{l}$ hemin for $30 \mathrm{~min}$. 22-R-OH $(5 \mu \mathrm{mol} / \mathrm{l})$ or $\mathrm{P}_{5}(5 \mu \mathrm{mol} / \mathrm{l})$ was added, and incubation was continued for an additional $5 \mathrm{~h}$. Values are expressed as means \pm S.E.M. of three independent experiments, each performed with three culture wells per condition. ${ }^{*} P<0 \cdot 001$ versus $22-\mathrm{R}-\mathrm{OH}$.

levels in Leydig cells from heat-stressed rats (Ewing \& Maines 1995) and $\mathrm{CdCl}_{2}$-treated rats (Ozawa et al. 2002).

Previous findings from our group demonstrated an inhibition of Leydig cell steroidogenesis by NO (Del Punta et al. 1996), and were further supported by other studies showing that NOS system modulates steroidogenesis (Kostic et al. 1999, Nee Pathak \& Lal 2008). Recently, we demonstrated that both NOS and $\mathrm{HO}$ systems are involved in adrenal gland ACTH-dependent steroidogenesis (Pomeraniec et al. 2004, Grion et al. 2007). In the past few years, $\mathrm{CO}$ has arised as a physiological messenger in the brain and cardiovascular system (Morse \& Choi 2002, Maines 2005, Bilban et al. 2008). It is well known that CO and NO share many biological properties. Increasing experimental evidence suggests the existence of a significant 'crosstalk' between $\mathrm{HO}$ and NOS systems (Calabrese et al. 2006, Chung et al. 2008). Therefore, based on the similarities of $\mathrm{CO}$ with $\mathrm{NO}$, we undertook the study of the effect of $\mathrm{HO}$ activity on steroidogenesis in MA-10 cells. The results shown herein demonstrate that a significant inhibition of hormone-induced $\mathrm{P}_{4}$ production was obtained when $\mathrm{HO}$ enzyme activity was increased by hemin treatment, suggesting that a product derived from $\mathrm{HO}$ activity may regulate steroidogenesis in MA-10 cells.

As we confirmed that $\mathrm{HO}$ system is involved in the regulation of steroid synthesis in MA-10 cells, and previous results showed that $\mathrm{CO}$ affects the activity of key enzymes in adrenal steroidogenesis (Pomeraniec et al. 2004), it is tempting to suggest that $\mathrm{CO}$ locally produced by $\mathrm{HO}$ could be a modulator of testicular steroidogenesis in general and of the activities of cytochrome P450 enzymes CYP11A (P450scc) and CYP17 (17 $\alpha$-hydroxylase-17,20 lyase), in particular. Regarding this, our experiments with $22-\mathrm{R}-\mathrm{OH}$ cholesterol and $\mathrm{P}_{5}$ suggest an inhibitory effect of $\mathrm{HO}$ on the activity of cytochrome $\mathrm{P} 450 \mathrm{scc}$, probably by the binding of $\mathrm{CO}$ to the heme in P450scc. This effect was reversible as the removal of hemin from the incubation media led to the full recovery of the cell steroidogenic capacity, in a similar way to that we have observed for $\mathrm{NO}$ (Del Punta et al. 1996). The inhibitory effect of $\mathrm{HO}$ induction was only observed on P450ssc activity, but not on P450scc protein expression.

Emerging evidence has suggested a possible role of $\mathrm{NO}$ in the inhibition of STAR protein expression in Leydig cells (Diemer et al. 2003, Herman \& Rivier 2006, Reddy et al. 2006), indicating the existence of at least one additional site of action of NO in the regulation of steroidogenesis (Del Punta et al. 1996). In agreement with the results obtained for NO, $\mathrm{HO}$ induction by hemin inhibited STAR protein expression, suggesting that $\mathrm{CO}$ may also regulate steroidogenesis by modulating cholesterol transport to the inner mitochondrial membrane.

It is known that STAR induction and processing (to the $30 \mathrm{kDa}$ form) are regulated by the levels of mitochondrial ATP and membrane potential respectively. The ATP levels regulate the exportation of arachidonic acid (AA) from the mitochondria, thus mitochondrial disruption with agents that reduce ATP content inhibits the exportation of AA
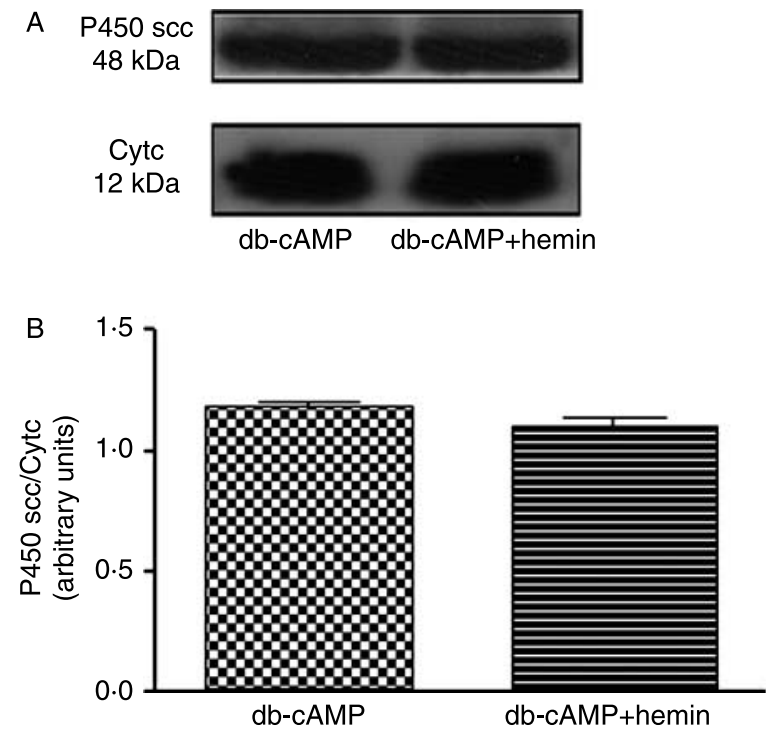

Figure 6 Effect of hemin treatment on cytochrome P450scc protein levels in MA-10 Leydig cells. Cells were preincubated with or without $10 \mu \mathrm{mol} / \mathrm{l} \mathrm{hemin} \mathrm{for} 30 \mathrm{~min}$. db-CAMP $(1 \mathrm{mmol} / \mathrm{l})$ was added, and incubation was continued for an additional $5 \mathrm{~h}$. Media were collected, crude mitochondrial fractions from MA-10 cells were isolated, and proteins were analyzed by western blot as described in Materials and Methods. Data were normalized to the $12 \mathrm{kDa}$ internal control cytochrome $c$. (A) A representative immunoblot for P450scc protein; (B) quantification of protein levels by scanning densitometry. Values are expressed as means \pm S.E.M. of three independent experiments. 

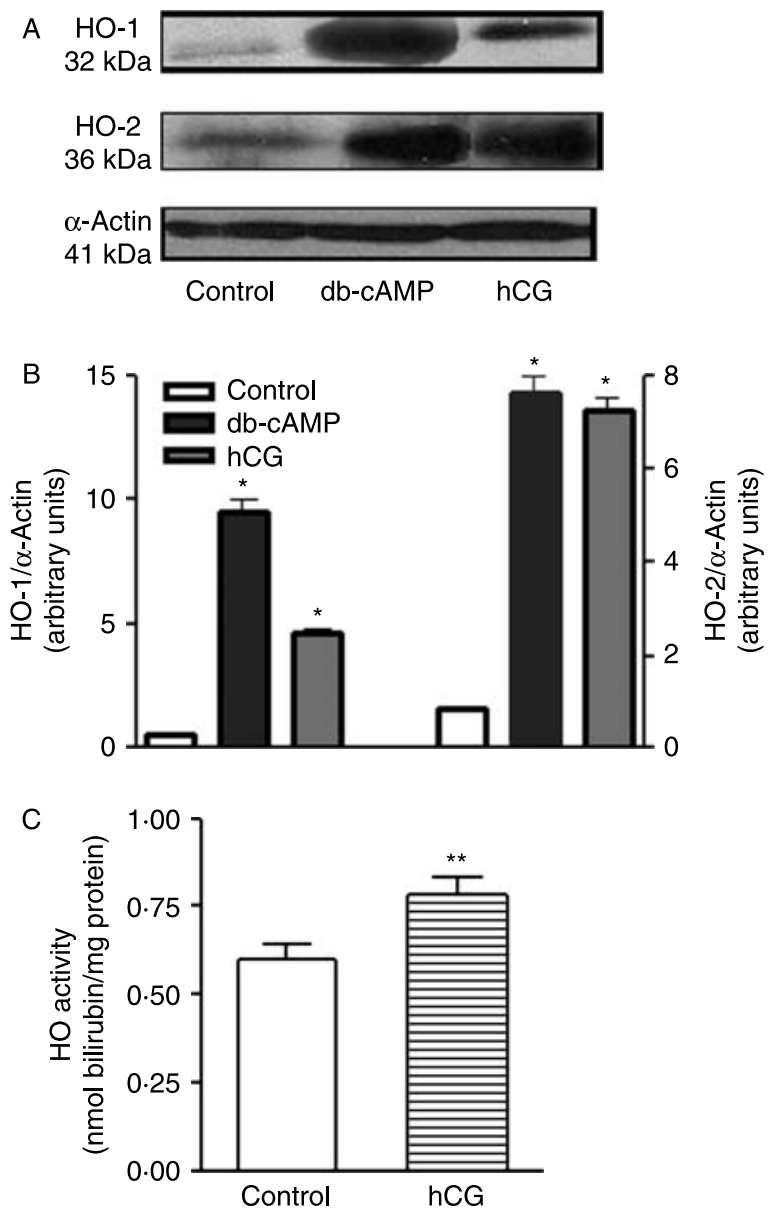

Figure 7 Effect of db-AMPc and hCG treatments on $\mathrm{HO}$ protein expression and activity in MA-10 Leydig cells. (A) Representative immunoblot for $\mathrm{HO}-1$ and $\mathrm{HO}-2$ proteins. Cells were incubated with $1 \mathrm{mmol} / \mathrm{l} \mathrm{db}-\mathrm{AMPc}$ or $20 \mathrm{ng} / \mathrm{ml} \mathrm{hCG}$ for $5 \mathrm{~h}$. Media were collected, microsomal fractions from MA-10 cells were isolated, and proteins were analyzed by western blot as described in Materials and Methods; (B) quantification of $\mathrm{HO}$ levels by scanning densitometry, corrected by corresponding $\alpha$-actin; (C) HO-specific activity was determined in microsomal fractions by monitoring the conversion of heme into bilirubin as described in Materials and Methods. Values are expressed as means \pm s.E.M. of three independent experiments. ${ }^{*} P<0 \cdot 001$ versus control, ${ }^{* *} P<0 \cdot 05$ versus control.

from the mitochondria, and consequently STAR protein induction (Duarte et al. 2007). In addition, mitochondrial membrane potential reduction inhibits the import and processing of STAR protein (Allen et al. 2007). As CO inhibits cytochrome $c$ oxidase, it affects ATP synthesis and membrane potential (Zuckerbraun et al. 2007). Therefore, it is possible that $\mathrm{CO}$, by affecting ATP levels and membrane potential, may reduce STAR protein by one or both of these mechanisms.

Noteworthy, contrary to its effect on STAR protein levels, hemin treatment induced an increase in STAR mRNA levels after $3 \mathrm{~h}$ of incubation with hCG, declining to normal values at $5 \mathrm{~h}$. In this sense, it should be noted that protein levels do not always temporarily correlate with the levels of its mRNA. In this line, Clark et al. (1995) showed that in rodent steroidogenic cells, post-transcriptional mechanisms regulate Star mRNA stability and degradation, thus altering the efficiency of protein synthesis.

In this study, we demonstrate that $\mathrm{HO}$ induction not only reduces STAR protein levels, but it also affects, at least, some post-transcriptional event leading to an increase in Star mRNA levels. To this respect, a recent study by Duan et al. (2009) has shown that silencing of an AURE-binding protein (zinc finger protein ZFP36L1/TIS11b), resulted in increased Star mRNA levels, while STAR protein induction was markedly reduced in MA-10 cells stimulated with Br-cAMP. These interesting findings tempt us to hypothesize that $\mathrm{HO}$ expression (or any of its metabolites) could modify Star mRNA levels by modulating some similar post-transcriptional regulatory mechanism.

The induction of $\mathrm{HO}$ isozymes by various hormonal stimuli has been previously demonstrated. In this sense, the induction of $\mathrm{HO}$ activity in liver by glucagon, insulin, and epinephrine (Bakken et al. 1972) and the expression levels of HO-1 in hepatic and kidney cells by glucagon and angiotensin II respectively have been reported (Immenschuh et al. 1998, Haugen et al. 2000). Recently, Pomeraniec et al. (2004) have shown that ACTH and 8-Br-cAMP induced $\mathrm{HO}-1$ expression, in adrenal cells, suggesting the involvement of the cAMP/protein kinase A (PKA) pathway. Transcriptional activation of the $\mathrm{Ho}-1$ gene via the PKA-signaling pathway has been demonstrated in rat hepatocyte cultures and vascular smooth muscle (Durante et al. 1997, Immenschuh et al. 1998). It has also been shown that HO-2 isozyme, which is constitutively expressed, can be induced by different factors (Liu et al. 2000, Tschugguel et al. 2001, Sacca et al. 2003).

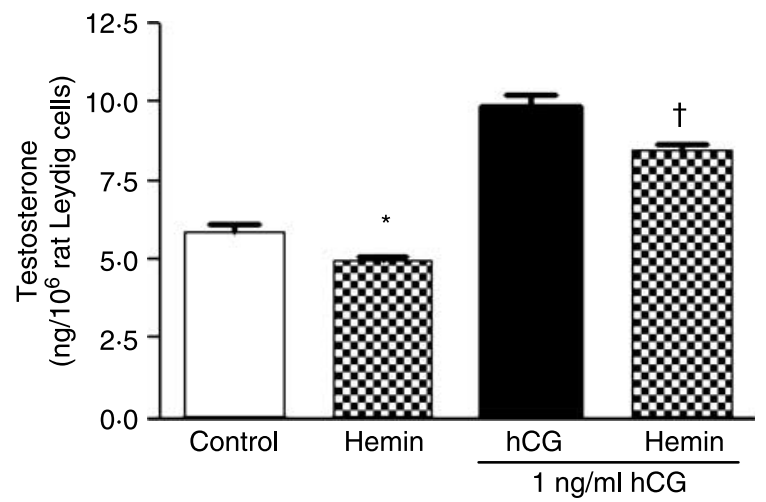

Figure 8 Effect of hemin on testosterone production in normal rat Leydig cells. Purified Leydig cells were preincubated for $30 \mathrm{~min}$ at $34{ }^{\circ} \mathrm{C}$ with or without $10 \mu \mathrm{mol} / /$ hemin. hCG $(1 \mathrm{ng} / \mathrm{ml})$ was added, and incubation was continued for $5 \mathrm{~h}$. Values are expressed as means \pm S.E.M. of three different experiments each performed with triplicate incubations per condition; ${ }^{*} P<0.01$ versus control, ${ }^{+} P<0 \cdot 01$ versus hCG $1 \mathrm{ng} / \mathrm{ml}$. 
In this work, we have demonstrated that both HO-1 and $\mathrm{HO}-2$ protein levels were increased by hCG or db-cAMP in MA-10 cells, indicating the involvement of cAMP/PKA signal transduction pathway in this mechanism. Our data are in agreement with that of Kutty \& Maines (1989) who described a selective induction of HO-1 isozyme in whole testis from hCG-treated rats, in vivo. In addition, Liu et al. (2000) presented evidences on the regulation of HO-2 levels in the testis by glucocorticoids and that developmental and tissue-specific factor(s) determine the generation of transcripts unique to the organ. The apparent exclusive use of rHO-2 by the mature testis is consistent with the possibility that HO-2 may play a role in male reproduction.

As proposed by Stocker (1990), the induction of HO-1 may play a role in cellular protection against oxidative stress. Many of the protective effects of $\mathrm{HO}-1$ induction have been attributed to two of its enzymatic products, CO (Otterbein \& Choi 2000, Maines \& Gibbs 2005, Desmard et al. 2007, Bilban et al. 2008) or bilirubin (a potent peroxyl radical scavenger; Clark et al. 2000, Erario et al. 2002). Moreover, HO-1 has been shown to have anti-inflammatory, antiapoptotic, and anti-proliferative effects in different systems (Morse \& Choi 2002, Bilban et al. 2008). In steroidogenic tissues, ACTH has been postulated to play a protective role in corticoadrenal cells, as it enhances Mn-SOD activity in ZF adrenal mitochondria (Raza \& Vinson 2000), exerts anti-apoptotic effects in primary cultures of bovine adrenocortical cells (Negoescu et al. 1995) and in intact adrenal glands cultures (Carsia et al. 1998). Besides, ACTH induces $\mathrm{HO}$ system, which appears to have antioxidant properties in Y1 cells (Pomeraniec et al. 2004). In MA-10 cells, we have observed that steroidogenesis inhibition by hemin is much more significant when the steroid production is supported by $22-\mathrm{R}-\mathrm{OH}$ cholesterol than when the cells are stimulated using either hCG or db-cAMP. Moreover, given the inhibition of P450scc activity and STAR protein expression, it can be expected that hemin would have a stronger inhibition of hCG or cAMP-induced steroidogenesis. However, this was not the case. Therefore, the induction of $\mathrm{HO}-1$ and $\mathrm{HO}-2$, which we observed in the presence of hCG or db-cAMP, suggests that $\mathrm{HO}$ system may be acting as a cytoprotective mechanism, as does in adrenal gland.

Although MA-10 cells are a widely used model to study Leydig cell steroidogenesis and are known to preserve most of the characteristic features of these cells, they are still tumoral cells that have undergone a series of mutations. However, similar results were obtained with rat Leydig cells, ratifying MA-10 cells as a useful experimental model.

In summary, both $\mathrm{HO}$ isoforms are present in MA-10 Leydig cells. Moreover, the induction of HO system could modulate steroidogenesis probably by the reversible binding of $\mathrm{CO}$ to the heme group of the cytochrome P450scc, as we previously described for NO (Del Punta et al. 1996). To our knowledge, this is the first report to show that induction of the HO system inhibits STAR protein expression, indicating that there are at least two steps in the steroidogenic pathway in which $\mathrm{HO}$ system may be acting. In addition, we provide evidence that LH/hCG induces an enzymatic system with known antioxidant properties in Leydig cells and that such mechanism could be functionally relevant to testicular physiology providing the organ with a higher capacity to respond to a wide range of physiological conditions. Then, the $\mathrm{HO} / \mathrm{CO}$ system may contribute to a fine net of regulation exerted on male reproductive function.

\section{Declaration of interest}

The authors declare that there is no conflict of interest that could be perceived as prejudicing the impartiality of the research reported.

\section{Funding}

This work was supported by grants from CONICET (PIP5525), University of Buenos Aires (X814) and ANPCYT (PICT 05-38281) to O P P.

\section{Acknowledgements}

The authors would like to thank Dr Carolina Mondillo (IBYME-CONICET) for her valuable and critical suggestions, and F Astort and E M Repetto for their helpful technical advice.

\section{References}

Acevedo CH \& Ahmed A 1998 Hemeoxygenase-1 inhibits human myometrial contractility via carbon monoxide and is upregulated by progesterone during pregnancy. Journal of Clinical Investigation 101 949-955.

Alexandreanu IC \& Lawson DM 2003 Heme oxygenase in the rat ovary: immunohistochemical localization and possible role in steroidogenesis. Experimental Biology and Medicine 228 59-63.

Allen JA, Shankara T, Janus P, Buck S, Diemer T, Hales KH \& Hales DB 2007 Energized, polarized, and actively respiring mitochondria are required for acute Leydig cell steroidogenesis. Endocrinology 148 2581-2582.

Ascoli M 1981 Characterization of several clonal lines of cultured Leydig tumor cells: gonadotropin receptors and steroidogenic responses. Endocrinology 108 88-95.

Ascoli M, Fanelli F \& Segaloff DL 2002 The lutropin/choriogonadotropin receptor, a 2002 perspective. Endocrine Reviews 23 141-174.

Bakken AF, Thaler MM \& Schmid R 1972 Metabolic regulation of heme catabolism and bilirubin production. I. Hormonal control of hepatic heme oxygenase activity. Journal of Clinical Investigation 51 530-536.

Bilban M, Haschemi A, Wegiel B, Chin BY, Wagner O \& Otterbein LE 2008 Heme oxygenase and carbon monoxide initiate homeostatic signaling. Journal of Molecular Medicine 86 267-279.

Bose HS, Whittal RM, Baldwin MA \& Miller WL 1999 The active form of the steroidogenic acute regulatory protein, StAR, appears to be a molten globule. PNAS 96 7250-7255.

Calabrese V, Butterfield DA, Scapagnini G, Stella AM \& Maines MD 2006 Redox regulation of heat shock protein expression by signaling involving nitric oxide and carbon monoxide: relevance to brain aging, neurodegenerative disorders, and longevity. Antioxidants \& Redox Signaling 8 444-477.

Carsia RV, Nagele RG, Morita Y, Tilly KI \& Tilly JL 1998 Models to elucidate the regulation of adrenal cell death. Endocrine Research 24 899-908. 
Charreau EH, Calvo JC, Nozu K, Pignataro O, Catt KJ \& Dufau ML 1981 Hormonal modulation of 3-hydroxy-3-methylglutaryl coenzyme A reductase activity in gonadotropin-stimulated and -desensitized testicular Leydig cells. Journal of Biological Chemistry 256 12719-12724.

Chung HT, Choi BM, Kwon YG \& Kim YM 2008 Interactive relations between nitric oxide (NO) and carbon monoxide (CO): heme oxygenase-1/ $\mathrm{CO}$ pathway is a key modulator in NO-mediated antiapoptosis and anti-inflammation. Methods in Enzymology 441 329-338.

Clark BJ, Soo SC, Caron KM, Ikeda Y, Parker KL \& Stocco DM 1995 Hormonal and developmental regulation of the steroidogenic acute regulatory protein. Molecular Endocrinology 9 1346-1355.

Clark JE, Foresti R, Green CJ \& Motterlini R 2000 Dynamics of haem oxygenase-1 expression and bilirubin production in cellular protection against oxidative stress. Biochemical Journal 348 615-619.

Del Punta K, Charreau EH \& Pignataro OP 1996 Nitric oxide inhibits Leydig cell steroidogenesis. Endocrinology 137 5337-5343.

Desmard M, Boczkowski J, Poderoso J \& Motterlini R 2007 Mitochondrial and cellular heme-dependent proteins as targets for the bioactive function of the heme oxygenase/carbon monoxide system. Antioxidants \& Redox Signaling 9 2139-2155.

Diemer T, Allen JA, Hales KH \& Hales DB 2003 Reactive oxygen disrupts mitochondria in MA-10 tumor Leydig cells and inhibits steroidogenic acute regulatory (StAR) protein and steroidogenesis. Endocrinology 144 2882-2891.

Duan H, Cherradi N, Feige JJ \& Jefcoate C 2009 cAMP-dependent posttranscriptional regulation of steroidogenic acute regulatory (STAR) protein by the zinc finger protein ZFP36L1/TIS11b. Molecular Endocrinology 23 497-509.

Duarte A, Castillo AF, Castilla R, Maloberti P, Paz C, Podestá EJ \& Cornejo Maciel F 2007 An arachidonic acid generation/export system involved in the regulation of cholesterol transport in mitochondria of steroidoigenic cells. FEBS Letters $\mathbf{5 8 1}$ 4023-4028.

Durante W, Kroll MH, Christodoulides N, Peyton KJ \& Schafer AI 1997 Nitric oxide induces heme oxygenase- 1 gene expression and carbon monoxide production in vascular smooth muscle cells. Circulation Research $80557-564$.

Erario MA, Gonzales S, Noriega GO \& Tomaro ML 2002 Bilirubin and ferritin as protectors against hemin-induced oxidative stress in rat liver. Cellular and Molecular Biology 48 877-884.

Ewing JF \& Maines MD 1995 Distribution of constitutive (HO-2) and heat-inducible (HO-1) heme oxygenase isozymes in rat testes: HO-2 displays stage-specific expression in germ cells. Endocrinology 136 2294-2302.

Frungieri MB, Gonzalez-Calvar SI, Parborell F, Albrecht M, Mayerhofer A \& Calandra RS 2006 Cyclooxygenase-2 and prostaglandin $\mathrm{F}_{2 \alpha}$ in Syrian hamster Leydig cells: inhibitory role on luteinizing hormone/human chorionic gonadotropin-stimulated testosterone production. Endocrinology 147 4476-4485.

Grion N, Repetto EM, Pomeraniec Y, Calejman CM, Astort F, Sanchez R, Pignataro OP, Arias P \& Cymeryng CB 2007 Induction of nitric oxide synthase and heme oxygenase activities by endotoxin in the rat adrenal cortex: involvement of both signaling systems in the modulation of ACTH-dependent steroid production. Journal of Endocrinology 194 11-20.

Hales DB 2002 Testicular macrophage modulation of Leydig cell steroidogenesis. Journal of Reproductive Immunology 57 3-18.

Hales KH, Diemer T, Ginde S, Shankar BK, Roberts M, Bosmann HB \& Hales DB 2000 Diametric effects of bacterial endotoxin lipopolysaccharide on adrenal and Leydig cell steroidogenic acute regulatory protein. Endocrinology 141 4000-4012.

Haugen EN, Croatt AJ \& Nath KA 2000 Angiotensin II induces renal oxidant stress in vivo and heme oxygenase- 1 in vivo and in vitro. Kidney International 58 144-152.

Herman M \& Rivier C 2006 Activation of a neural brain-testicular pathway rapidly lowers Leydig cell levels of the steroidogenic acute regulatory protein and the peripheral-type benzodiazepine receptor while increasing levels of neuronal nitric oxide synthase. Endocrinology 147 624-633.
Immenschuh S, Kietzmann T, Hinke V, Wiederhold M, Katz N \& MullerEberhard U 1998 The rat heme oxygenase-1 gene is transcriptionally induced via the protein kinase A signaling pathway in rat hepatocyte cultures. Molecular Pharmacology 53 483-491.

Kostic TS, Andric SA, Maric D, Stojilkovic SS \& Kovacevic R 1999 Involvement of inducible nitric oxide synthase in stress-impaired testicular steroidogenesis. Journal of Endocrinology 163 409-416.

Liu N, Wang X, McCoubrey WK \& Maines MD 2000 Developmentally regulated expression of two transcripts for heme oxygenase-2 with a first exon unique to rat testis: control by corticosterone of the oxygenase protein expression. Gene 241 175-183.

Llesuy SF \& Tomaro ML 1994 Heme oxygenase and oxidative stress. Evidence of involvement of bilirubin as physiological protector against oxidative damage. Biochimica et Biophysica Acta 1223 9-14.

Lyall F, Barber A, Myatt L, Bulmer JN \& Robson SC 2000 Hemeoxygenase expression in human placenta and placental bed implies a role in regulation of trophoblast invasion and placental function. FASEB Journal $14208-219$.

Maines MD 1997 The heme oxygenase system: a regulator of second messenger gases. Annual Review of Pharmacology and Toxicology 37 517-554.

Maines MD 2005 The heme oxygenase system: update 2005. Antioxidants and Redox Signaling 7 1761-1766.

Maines MD \& Gibbs PE 200530 some years of heme oxygenase: from a "molecular wrecking ball" to a "mesmerizing" trigger of cellular events. Biochemical and Biophysical Research Communications 338 568-577.

McCoubrey WK Jr, Ewing JF \& Maines MD 1992 Human heme oxygenase2: characterization and expression of a full-length cDNA and evidence suggesting that the two HO-2 transcripts may differ by choice of polyadenylation signal. Archives of Biochemistry and Biophysics 295 13-20.

McCoubrey WK Jr, Huang TJ \& Maines MD 1997 Isolation and characterization of a cDNA from the rat brain that encodes hemoprotein heme oxygenase-3. European Journal of Biochemistry 247 725-732.

Middendorff R, Kumm M, Davidoff MS, Holstein AF \& Muller D 2000 Generation of cyclic guanosine monophosphate by heme oxygenases in the human testis - a regulatory role for carbon monoxide in Sertoli cells? Biology of Reproduction 63 651-657.

Mondillo C, Patrignani Z, Reche C, Rivera E \& Pignataro O 2005 Dual role of histamine in modulation of Leydig cell steroidogenesis via HRH1 and HRH2 receptor subtypes. Biology of Reproduction 73 899-907.

Mondillo C, Falus A, Pignataro O \& Pap E 2007 Prolonged histamine deficiency in histidine decarboxylase gene knockout mice affects Leydig cell function. Journal of Andrology 28 86-91.

Mondillo C, Pagotto RM, Piotrkowski B, Reche CG, Patrignani ZJ, Cymeryng CB \& Pignataro OP 2009 Involvement of nitric oxide synthase in the mechanism of histamine-induced inhibition of Leydig cell steroidogenesis via histamine receptor subtypes in Sprague-Dawley rats. Biology of Reproduction 80 144-152.

Morse D \& Choi AM 2002 Heme oxygenase-1: the "emerging molecule" has arrived. American Journal of Respiratory Cell and Molecular Biology 27 8-16.

Nee Pathak ND \& Lal B 2008 Nitric oxide: an autocrine regulator of Leydig cell steroidogenesis in the Asian catfish, Clarias batrachus. General and Comparative Endocrinology 158 161-167.

Negoescu A, Labat-Moleur F, Defaye G, Mezin P, Drouet C, Brambilla E, Chambaz EM \& Feige JJ 1995 Contribution of apoptosis to the phenotypic changes of adrenocortical cells in primary culture. Molecular and Cellular Endocrinology 110 175-184.

Niess AM, Passek F, Lorenz I, Schneider EM, Dickhuth HH, Northoff H \& Fehrenbach E 1999 Expression of the antioxidant stress protein heme oxygenase-1 (HO-1) in human leukocytes. Free Radical Biology and Medicine 26 184-192.

Otterbein LE \& Choi AM 2000 Heme oxygenase: colors of defense against cellular stress. American Journal of Physiology. Lung Cellular and Molecular Physiology 279 L1029-L1037.

Ozawa N, Goda N, Makino N, Yamaguchi T, Yoshimura Y \& Suematsu M 2002 Leydig cell-derived heme oxygenase-1 regulates apoptosis of premeiotic germ cells in response to stress. Journal of Clinical Investigation 109 $457-467$. 
Payne AH, Downing JR \& Wong KL 1980 Luteinizing hormone receptors and testosterone synthesis in two distinct populations of Leydig cells. Endocrinology 106 1424-1429.

Pignataro OP \& Ascoli M 1990a Epidermal growth factor increases the labeling of phosphatidylinositol 3,4-bisphosphate in MA-10 Leydig tumor cells. Journal of Biological Chemistry 265 1718-1723.

Pignataro OP \& Ascoli M $1990 b$ Studies with insulin and insulin-like growth factor-I show that the increased labeling of phosphatidylinositol-3,4bisphosphate is not sufficient to elicit the diverse actions of epidermal growth factor on MA-10 Leydig tumor cells. Molecular Endocrinology $4758-765$.

Pignataro OP, Radicella JP, Calvo JC \& Charreau EH 1983 Mitochondrial biosynthesis of cholesterol in Leydig cells from rat testis. Molecular and Cellular Endocrinology 33 53-67.

Pomeraniec Y, Grion N, Gadda L, Pannunzio V, Podesta EJ \& Cymeryng CB 2004 Adrenocorticotropin induces heme oxygenase-1 expression in adrenal cells. Journal of Endocrinology 180 113-124.

Raza FS \& Vinson GP 2000 Adrenocortical expression of MnSOD. Endocrine Research 26 959-963.

Reddy MM, Mahipal SV, Subhashini J, Reddy MC, Roy KR, Reddy GV, Reddy PR \& Reddanna P 2006 Bacterial lipopolysaccharide-induced oxidative stress in the impairment of steroidogenesis and spermatogenesis in rats. Reproductive Toxicology 22 493-500.

Sacca GB, Saenz DA, Jaliffa CO, Minces L, Keller Sarmiento MI \& Rosenstein RE 2003 Photic regulation of heme oxygenase activity in the golden hamster retina: involvement of dopamine. Journal of Neurochemistry $\mathbf{8 5}$ 534-542.

Shiraishi K \& Naito K 2005 Increased expression of Leydig cell haem oxygenase-1 preserves spermatogenesis in varicocele. Human Reproduction 20 2608-2613.

Stocco DM 2001 StAR protein and the regulation of steroid hormone biosynthesis. Annual Review of Physiology 63 193-213.
Stocco DM \& Clark BJ 1996 Regulation of the acute production of steroids in steroidogenic cells. Endocrine Reviews 17 221-244.

Stocco DM, Wang X, Jo Y \& Manna PR 2005 Multiple signaling pathways regulating steroidogenesis and steroidogenic acute regulatory protein expression: more complicated than we thought. Molecular Endocrinology 19 2647-2659.

Stocker R 1990 Induction of haem oxygenase as a defence against oxidative stress. Free Radical Research Communications 9 101-112.

Trakshel GM \& Maines MD 1988 Detection of two heme oxygenase isoforms in the human testis. Biochemical and Biophysical Research Communications 154 285-291.

Tschugguel W, Stonek F, Zhegu Z, Dietrich W, Schneeberger C, Stimpfl T, Waldhoer T, Vycudilik W \& Huber JC 2001 Estrogen increases endothelial carbon monoxide, heme oxygenase 2, and carbon monoxidederived cGMP by a receptor-mediated system. Journal of Clinical Endocrinology and Metabolism 86 3833-3839.

Verma A, Hirsch DJ, Glatt CE, Ronnett GV \& Snyder SH 1993 Carbon monoxide: a putative neural messenger. Science 259 381-384.

Zhuo M, Small SA, Kandel ER \& Hawkins RD 1993 Nitric oxide and carbon monoxide produce activity-dependent long-term synaptic enhancement in hippocampus. Science 260 1946-1950.

Zuckerbraun BS, Chin BY, Bilban M, de Costa d'Avila J, Rao J, Billiar TR \& Otterbein LE 2007 Carbon monoxide signals via inhibition of cytochrome $c$ oxidase and generation of mitochondrial reactive oxygen species. FASEB Journal 21 1099-1106.

Received in final form 28 July 2009

Accepted 31 July 2009

Made available online as an Accepted Preprint

31 July 2009 